\title{
Perlindungan Hak Dasar Anak pada Masa Pandemi Covid-19 di Kota Medan
}

\section{Protection of Children's Basic Right During the Covid-19 Pandemic Period in the City of Medan}

\author{
Muhammad Ansori Lubis* \\ Program Studi Ilmu Hukum, Fakultas Hukum, Universitas Darma Agung, Indonesia
}

*Coresponding Email:Ansori.UDA@gmail.com

\begin{abstract}
Abstrak
Anak sebagai generasi penerus diharapkan menjadi tumpuan bangsa di masa yang akan mendatang. Oleh karena itu sudah menjadi kewajiban untuk memenuhi hak dasar anak bagi seluruh elemen bangsa. Akan tetapi di masa pandemi sekarang ini, Peraturan Walikota Medan Nomor 11 Tahun 2020 tentang Karantina Kesehatan Dalam Rangka Percepatan Penanganan Corona Virus Disease 2019 (Covid-19) Di Kota Medan, masihlah belum mengakomodir pemenuhan hak dasar anak. Penelitian ini bertujuan untuk mengetahui perlindungan hak dasar anak pada masa pandemic covid 19 di kota medan. Penelitian ini merupakan penelitian normatif, yaitu penelitian yang membahas aspek hukum dengan melakukan penelusuran bahan kepustakaan (library research) yang berorientasi kepada peraturan perundang-undangan yang berlaku.Pemerintah Kota Medan Beserta Dewan Perwakilan Rakyat Daerah Kota Medan haruslah segera menerbitkan produk hukum daerah setingkat Peraturan Daerah (Perda) untuk menjamin perlindungan dan pemenuhan hak-hak dasar anak di masa pandemi Covid-19.
\end{abstract}

Kata Kunci: Hak Dasar Anak, Kota Medan, Pandemi Covid-19, Perlindungan Anak.

\begin{abstract}
Children as the next generation are the foundation of the nation's future. Therefore fulfilling the basic rights of children is an obligation that must be realized by every element of the nation. However, in the current pandemic, Medan Mayor Regulation No. 11 of 2020 concerning Health Quarantine in the Context of Handling Corona Virus Disease 2019 (Covid-19) in Medan City, still does not accommodate the fulfillment of children's basic rights. This study aims to determine the protection of children's basic rights during the Covid 19 pandemic in Medan. This research is a normative research, namely research that discusses legal aspects by conducting a search of library materials (library research) which is oriented towards the prevailing laws and regulations. The Medan City Government and the Medan City House of Representatives must immediately issue regional legal products at the level of the Regional Regulation (Perda) to ensure the protection and fulfillment of children's basic rights during the Covid-19 pandemic. Keywords: Basic Rights of Children, Medan City, Covid-19 Pandemic, Child Protection.
\end{abstract}

How to Cite: Lubis, M.A. (2020). Perlindungan Hak Dasar Anak pada Masa Pandemi Covid-19 di Kota Medan. Jurnal Mercatoria. 13 (2): 188-203. 


\section{PENDAHULUAN}

Setiap anak yang belum mencapai kedewasaan membutuhkan perlindungan dan pengasuhan dari keluarga. Keluarga merupakan lingkungan awal dalam pertumbuhan dan kesejahteraan semua anggotanya dan terutama anak-anak, oleh karena itu untuk perkembangan kepribadian yang baik, anak harus tumbuh berkembang di lingkungan keluarga dalam suasana yang bahagia, penuh cinta kasih dan pengertian. Keluarga mengajarkan anak mengenai nilai-nilai agama, kasih sayang dan saling menghormati. Keluarga juga harus mempersiapkan anak untuk dapat hidup bermasyarakat.

Kemudian lingkungan kedua dalam pertumbuhan dan perkembangan anak setelah keluarga adalah lingkungan sekolah. Apabila di lingkungan keluarga pertumbuhan dan perkembangan anak dimulai dengan suasana bahagia, penuh cinta kasih dan pengertian. Di lingkungan sekolah anak diajarkan mengenai ketegasan, kepemimpinan, tenggang rasa, budipekerti, toleransi dan menghargai perbedaan, tanggungjawab, kerjasama, serta ilmu pengetahuan.

Selain keluarga dan sekolah, pemerintah juga bertanggung jawab untuk melindungi tumbuh dan kembangnya anak. oleh karena itu pemerintah memiliki kewajiban untuk memberikan perlindungan terhadap pertumbuhan dan perkembangan anak.

Perlindungan yang diberikan negara kepada anak dibagi menjadi dua bagian yaitu (Said, 2018):

1. Perlindungan anak yang bersifat yuridis, yang meliputi:
a. Perlindungan dalam bidang hukum publik, dan
b. Perlindungan dalam bidang hukum keperdataan;

2. Perlindungan anak yang bersifat non yuridis, meliputi:
a. Perlindungan dalam bidang sosial,
b. Perlindungan dalam bidang kesehatan, dan
c. Perlindungan dalam bidang pendidikan.

Menurut Barda Nawawi Arief bahwa perlindungan hak asasi anak adalah suatu usaha atau upaya perlindungan hukum yang berkaitan dengan segala kebebasan dan hak asasi anak (fundamental rights and freedom of children) agar terwujud kesejaheraan anak.

Secara umum perlindungan anak merupakan suatu tata kehidupan dan penghidupan anak yang bertujuan untuk 
menjamin pertumbuhan dan perkembangan anak dengan wajar, baik secara rohani, jasmani maupun kehidupan sosialnya.

Negara berkewajiban menciptakan rasa aman dan memberikan perlindungan hukum kepada setiap anak Indonesia agar mereka tumbuh serta berkembang secara wajar dan berperan serta dalam pembangunan. Perlindungan hukum terhadap anak merupakan upaya perlindungan terhadap anak yang berhubungan dengan kebebasan dan hak azasi anak (Arief, 2005).

Perlindungan Anak juga diartikan sebagai segala kegiatan yang menjamin dan melindungi anak dan hak-haknya agar dapat hidup, tumbuh, berkembang, dan berpartisipasi secara optimal sesuai dengan harkat dan martabat kemanusiaan serta mendapat perlindungan dari kekerasan dan diskriminasi. Perlindungan anak adalah suatu kegiatan bersama yang bertujuan mengusahakan pengamanan, pengadaan, dan pemenuhan kesejahteraan rohaniah dan jasmaniah anak yang sesuai dengan kepentingannya dan hak asasinya (Gosita, 2004).

Perlindungan anak mempunyai spektrum yang cukup luas (Syamsuddin, 2014). Dalam berbagai dokumen dan pertemuan internasional terlihat bahwa perlunya perlindungan hukum bagi anak dapat meliputi berbagai aspek, yaitu perlindungan terhadap hak-hak asasi dan kebebasan anak, perlindungan anak dalam proses peradilan perlindungan kesejahteraan anak (dalam lingkungan keluarga, pendidikan dan lingkungan sosial), perlindungan anak dalam masalah penahanan dan perampasan kemerdekaan, perlindungan anak dari segala bentuk eksploitasi (perbudakan, perdagangan anak pelacuran, pornografi, perdagangan/penyalahgunaan obatobatan, memperalat anak dalam melakukan kejahatan dan sebagainya), perlindungan terhadap anak-anak jalanan, perlindungan anak dari akibat-akibat peperangan/konflik bersenjata, dan perlindungan anak terhadap tindakan kekerasan (Fahlevi, 2015).

Setiap anak sejak kelahirannya berhak untuk mendapatkan identitas diri yang yang dituangkan dalam akta kelahiran. Bukti identitas yang berlaku dalam akta kelahiran merupakan suatu bentuk perlindungan hukum terhadap anak dan pengakuan formal mengenai keberadaan anak, secara individual terhadap negara dan status anak dalam hukum. Secara yuridis anak berhak untuk mendapatkan perlindungan. Semakin modern suatu negara, seharusnya semakin besar perhatiannya dalam menciptakan kondisi yang kondusif bagi tumbuh 
kembang anak dalam rangka perlindungan (Syamsuddin, 2014).

Perlindungan anak merupakan perwujudan adanya keadilan dalam suatu masyarakat, dengan demikian perlindungan anak diusahakan dalam berbagai bidang kehidupan bernegara dan masyarakat. Kegiatan perlindungan anak membawa akibat hukum, baik dalam kaitannya dalam hukum tertulis maupun hukum tidak tertulis. Hukum merupakan jaminan bagi kegiatan perlindungan anak. Kepastian hukum perlu diusahakan demi kelangsungan kegiatan pelindungan anak dan mencegah penyelewengan yang membawa akibat negatif yang tidak diinginkan dalam pelaksanaan perlindungan anak (Gosita, 2004).

Untuk itu seluruh elemen negara khususnya pemerintah baik itu di tingkat pusat maupun daerah haruslah dapat memberikan perlindungan kepada anak baik secara fisik maupun mental dan juga memjamin pemenuhan hak-hak dasar yang wajib didapatkan oleh setiap anak.

Saat sekarang ini dimasa pandemi Covid-19 sedang melanda dunia dan diberlakukannya protokol kesehatan demi mencegah penyebaran pandemi Covid-19, anak semakin kesulitan untuk mendapatkan hak-hak dasarnya. Sebagai contoh, diberhentikannya proses belajar di sekolah untuk sementara tentunya telah menggangu pemenuhan hak dasar anak untuk mendapatkan pendidikan. Kemudian dengan adanya pembatasan sosial tentunya mengganggu hak dasar anak untuk mendapatkan masa tumbuh dan berkembang yang normal dan bahagia.

Akibat dari terganggunya pemenuhan hak-hak dasar anak yang diakibatkan oleh protokol kesehatan dalam pencegahan dan penanganan pandemi Covid-19, tentunya akan berakibat kepada proses tumbuh dan berkembangnya anak terutama terhadap perkembangan fisik, mental, kecerdasan, watak, karakter dan perilaku anak. Apalagi masih belum diketahui dengan pasti, kapan pandemi Covid-19 akan berakhir dan kapan kehidupan masyarakat akan kembali normal.

Dikarenakan masih belum dapat diprediksi kapan berakhirnya pandemi Covid-19, pemerintah Republik Indonesia demi menjaga kelangsungan kehidupan berbangsa dan bernegara terutama di bidang ekonomi, menawarkan suatu alternatif agar masyarakat dapat melakukan aktifitas di luar rumah dimasa pandemi Covid-19. Alternatif tersebut dinamakan kehidupan Normal Baru atau New Normal. New Normal merupakan 
suatu kondisi pelaksanaan aktifitas sosialekonomi masyarakat seperti keadaan sebelum pandemi Covid-19 melanda dengan ditambahkannya pelaksanaan protokol kesehatan yang ketat seperti:

1. Penggunaan masker di setiap aktifitas di luar rumah;

2. Mengatur jarak antar individu saat berinteraksi;

3. Pemeriksaan suhu tubuh saat akan memasuki gedung-gedung serta fasilitas publik;

4. Penyemprotan disinfektan untuk kendaraan;

5. Mencuci tangan dengan sabun saat akan memasuki fasilitas publik, dan lain sebagainya.

Dengan diterapkannya New Normal, pemerintah berharap penyelenggaraan aktifitas ekonomi akan dapat dilakukan sehingga ekonomi negara tidak berhenti ataupun melambat. Pelaksanaan New Normal juga akan diterapkan dalam penyelenggaraan proses belajar di sekolah sehingga para siswa dapat belajar dengan cara bertatap muka dengan guru di sekolah. Kondisi ini berlaku apabila sekolah tersebut berada dalam zona hijau. Yang dimaksud dengan zona hijau adalah wilayah atau daerah yang tidak memiliki kasus Covid-19 (Pasys, 2020).
Dari pengertian zona hijau tersebut, dapat kita simpulkan bahwa saat ini hanya ada sedikit wilayah di Indonesia yang dapat menerapkan kegiatan belajar di sekolah melalui proses tatap muka. Ini tentu nya akan menghambat proses pemenuhan hak dasar anak di bidang pendidikan.

Kota Medan sebagai ibukota Provinsi Sumatera Utara memegang rekor penyebaran dan jumlah pasien Covid-19 tertinggi di Provinsi Sumatera Utara. Untuk menekan penyebaran dan mengoptimalkan penanganan Covid-19 di Kota Medan, pemerintah Kota Medan melalui pelaksana tugas Walikota Medan telah menerbitkan Peraturan Walikota Medan Nomor 11 Tahun 2020 tentang Karantina Kesehatan Dalam Rangka Percepatan Penanganan Corona Virus Disease 2019 (Covid-19) Di Kota Medan (Perwal Medan Nomor 11 Tahun 2020). Perwal Medan Nomor 11 Tahun 2020 mengatur mengenai upaya pencegahan dan penanganan Covid-19 di Kota Medan melalui karantina kesehatan dan melalui pelaksanaan protokol kesehatan Covid-19 yang di dalamnya terdapat aturan mengenai hak serta kewajiban pemerintah Kota Medan, Gugus Tugas Percepatan Penanganan Covid-19 Kota Medan, dan masyarakat Kota Medan. 
Akan tetapi Perwal Medan Nomor 11 Tahun 2020 tidak mengakomodir mengenai pemenuhan hak-hak dasar anak ataupun kewajiban pemerintah Kota Medan dan masyarakat Kota Medan dalam melindungi proses tumbuh kembang anak dalam menghadapi masa pandemi Covid-19. Dalam bidang pendidikan, pemerintah Kota Medan telah melarang sekolah untuk memungut biaya sekolah, biaya pendaftaran dan biaya pembangunan kepada peserta didik tingkat pendidikan anak usia dini (PAUD); taman kanak-kanak (TK); dan sekolah menengah pertama (SMP) selama masa pandemi Covid-19 melalui Surat Edaran Nomor 420/3481 tanggal 14 Mei 2020 tentang Keringanan Biaya Pendidikan pada perguruan swasta, namun dikarenakan larangan tersebut hanya berupa surat edaran, pemerintah Kota Medan tidak dapat memberikan hukuman atau sanksi kepada sekolah yang tetap memungut biaya dari siswa peserta didik (Tarigan, 2020).

Dalam hal kekerasan terhadap anak selama masa pandemi Covid-19, jumlah kasusnya juga mengalami peningkatan. Pada tanggal 19 Juni 2020 di Kota Medan telah terjadi tindak kekerasan kepada dua orang anak yang dilakukan oleh ayah tiri yang menyebabkan tewas nya kedua anak tersebut. Kejadian itu terjadi dikarenakan kedua anak yang menjadi korban meminta dibelikan es kepada ayah tiri nya, ayah tiri korban tidak membelikan es krim dikarenakan tidak memiliki uang, selayaknya anak kecil kedua korban merengek dan memaksa agar dibelikan es, akan tetapi ayah tiri kedua korban memukul dan membunuh kedua korban dan membuang mayat kedua korban ke dalam parit di sebelah sebuah sekolah swasta di Kota Medan (Wismabrata, 2020). Kasus ini merupakan salah satu dari sekian banyak kasus kekerasan terhadap anak yang dikarenakan berkurangnya pendapatan orangtua dimasa pandemi Covid-19 sehingga anak menjadi sasaran pelampiasan.

Dari contoh-contoh kasus di atas, perlindungan dan pemenuhan hak-hak dasar anak di Kota Medan pada masa pandemi Covid-19 masihlah rendah. Dan jika melihat pada kebijakan pemerintah daerah Kota Medan saat ini, tidak seluruhnya memberikan dampak secara menyeluruh pada semua lapisan masyarakat (Syaputra, 2017), khususnya anak. Dalam kondisi apapun pemenuhan hak dasar anak tidaklah boleh diabaikan.

Pemerintah Kota Medan sebagai penyelenggara negara di daerah yang berkewajiban untuk melindungi, 
mensejahterakan dan mencerdaskan rakyat di Kota Medan, haruslah mampu untuk melindungi dan memenuhi hak-hak dasar anak yang merupakan generasi penerus yang akan meregenerasi birokrasi Kota Medan di masa depan. Oleh karena itu dalam merancang dan menerbitkan regulasi dimasa pandemi Covid-19 pemerintah kota medan harus memperhatikan serta mengedepankan perlindungan terhadap hak-hak dasar anak di dalamnya.

Berdasarkan latar belakang yang telah diuraikan diatas maka penelitian ini mengangkat judul mengenai Perlindungan Hak Dasar Anak Pada Masa Pandemi Di Kota Medan.

\section{METODE PENELITIAN}

Penelitian ini merupakan penelitian normatif, yaitu penelitian yang membahas aspek hukum dengan melakukan penelusuran bahan kepustakaan (library research) yang berorientasi kepada peraturan perundang-undangan yang berlaku (Soerjono Soekanto dan Sri Mamudji, 2003).

Metode penelitian hukum normatifadalah studi yang meneliti dokumen, yang menggunakan berbagai literatur sepertiundang-undang, putusan pengadilan, teori hukum, dan bisa jadi pendapat para sarjana. Penelitian iniakan menggunakan analisis kualitatif dengan menjelaskan data dan teori yang ada yang terkait dengan jawaban masalah (MYA Saputra \& Mirza Nasution, 2018).

Sumber data yang digunakan dalam penelitian ini adalah data sekunder yang berupa bahan hukum primer, bahan hukum sekunder dan bahan hukum tersier.

Prosedur pengumpulan data dalam penelitian ini dilakukan melalui serangkaian aktivitas pengumpulan bahan-bahan yang dapat membantu terselenggaranya penelitian, terutama dengan melakukan studi kepustakaan. Dalam hal ini melalui penelitian terhadap dokumen-dokumen yang merupakan bahan hukum primer, kemudian melakukan penelitian terhadap bahan hukum sekunder.

Tujuan dan kegunaan studi kepustakaan pada dasarnya adalah menunjukan jalan pemecahan permasalahan penelitian. Penelitian kepustakaan dilakukan melalui inventarisasi dokumen-dokumen yang merupakan bahan hukum yang akan dijadikan sebagai bahan penulisan (Sunggono, 2003).

Analisis data (bahan hukum) merupakan proses pencarian dan perencanaan secara sistematis terhadap 
semua dokumen dan bahan lain yang telah dikumpulkan agar dapat memahami apa yang akan ditemukan dan dapat menyajikannya hasil penelitian dengan jelas. Untuk dapat memecahkan dan menguraikan masalah yang akan diteliti berdasarkan bahan hukum yang diperoleh maka diperlukan adanya teknik analisis bahan hukum.

Penelitian ini menggunakan analisis kualitatif yakni dengan menafsirkan gejala yang terjadi atau yang akan terjadi, tetapi bukan karena suatu kondisi yang mendominasi atau keceneruangan. Analisis bahan hukum dilakukan dengan cara mengumpulkan semua bahan hukum yang diperlukan dan kemudian menghubungkannya dengan permasalahan yang ada.

\section{HASIL DAN PEMBAHASAN}

\section{Anak dalam Pembangunan Daerah}

Dalam suatu negara yang demokratis dan menjunjung Hak Asasi Manusia (HAM), partisipasi merupakan suatu pengakuan negara akan pentingnya keberadaan dan peran serta rakyat dalam pembangunan.Di era keterbukaan, hak atas partisipasi bukan hanya ditujukan dan domain bagi orang dewasa saja, anak-anak juga diberikan hak yang sama dan memiliki kesempatan untuk berpartisipasi dalam pembangunan. Tentunya bentuk partisipasi anak tidak sepenuhnya sama dengan orang dewasa. Penggunaan hak partisipasi anak disesuaikan dengan kematangan umur, mental dan kemampuan berpikir anak serta terbatas pada hal-hal yang berkaitan dengan kepentingan pemenuhan hak anak.

Begitu pentingnya hak partisipasi anak, maka Konvensi Hak Anak (Convention on the Right of the Child) menjadikan hak partisipasi sebagai salah satu dari hak dasar anak yang harus dipenuhi. Dengan diberikannya hak partisipasi bagi anak dalam pembangunan menempatkan anak sebagai pihak yang harus diikutsertakan dalam proses pembangunan sehingga hasil-hasil pembangunan benar-benar berpihak, memberi manfaat dan berguna bagi anak.

Secara hukum, hak partisipasi anak diatur dalam Pasal 10 Undang Undang Nomor 35 Tahun 2014 tentang Perlindungan Anak yang berbunyi, "Setiap anak berhak menyatakan dan didengar pendapatnya, menerima, mencari, dan memberikan informasi sesuai dengan tingkat kecerdasan dan usianya demi pengembangan dirinya 
sesuai dengan nilai-nilai kesusilaan dan kepatutan".Pasal 24 memerintahkan pada negara dan pemerintah untuk menjamin agar anak dapat berpartisipasi dalam pembangunan dan dalam kehidupan sosial kemasyarakatan, "Negara dan pemerintah menjamin anak untuk dapat mempergunakan haknya dalam menyampaikan pendapat sesuai dengan usia dan tingkatkecerdasan anak".

Hak partisipasi anak akan lebih efektif apabila disalurkan melalui suatu perkumpulan, kelompok atau forum sehingga aspirasi atau suara anak tersebut bisa mewakili kepentingan anak secara luas berkaitan dengan pemenuhan hak-hak anak. Dengan disalurkan melalui kelompok-kelompok akan memudahkan pihak yang berkewajiban dan bertanggung jawab terhadap pemenuhan hak anak dalam menampung dan menentukan skala prioritas pemenuhan hak anak yang harus segera dilaksanakan sesuai dengan aspirasi, suara dan pendapat anak.

Selama ini partisipasi anak di daerah kurang mendapat perhatian, hal ini disebabkan oleh kekeliruan pemahaman bahwa cara berpikir anak yang belum matang sehingga tidak perludi pertimbangkan, dan dianggap belum mampu ikut serta dalam pembangunan. Padahal yang justru perlu didengar pendapatnya adalah anak, berkenaan masa depan bangsa dan negara yang akan mereka jalani nantinya. Pemenuhan hak partisipasi anak merupakan jembatan komunikasi antara anak-anak dan pemerintah dalam rangka penghormatan, pemenuhan dan perlindungan hak-hak anak lainnya.

Pemenuhan hak ataspartisipasi anak juga merupakan salah satu indikator kabupaten/kota layak anak, dimana pemerintah kabupaten/kota berkewajiban untuk memberi ruang bagi anak-anak mengeluarkan pendapat dan berpartisipasi aktif pada proses pembangunan (Firdaus, 2015).

Sudah sewajibnya pemerintah pusat dan pemerintah daerah membimbing dan mendengarkan aspirasi anak dikarenakan hal tersebut merupakan bagian dari mempersiapkan anak-anak untuk mengambil alih kepemimpinan bangsa dan negara dimasa depan. Dengan mempartisipasikan anak dalam pembangunan daerah, itu berarti pemerintah sedang mengenalkan dam mengajarkan anak atas budaya demokrasi dan politik yang baik, dari hal itu anak akan belajar untuk menghargai perbedaan pendapat serta kebhinekaan sehingga akan membentuk karakter anak 
yang memiliki tanggung jawab, tenggang rasa serta kepedulian sosial, yang akan mewujudkan generasi penerus bangsa yang moderat dan memiliki integritas.

\section{Hak-hak Dasar Anak}

Bencana adalah sebuah kejadian baik yang disebabkan oleh faktor manusia maupun faktor alam yang menyebabkan penderitaan seperti kematian, luka, kehilangan tempat tinggal atau hancurnya ekonomi yang melumpuhkan kemampuan masyarakat untuk mengatasinya. Ini merupakan dampak dari sebuah situasi berbahaya terhadap masyarakat. Pada saat terjadi bencana, anak-anak pada umumnya akan menghadapi resiko yang dapat membahayakan jiwa serta kepentingannya. Walaupun sebagian anak-anak menghadapi resiko yang lebih kecil karena mereka tinggal bersama dengan orang tua mereka atau orang dewasa lain, tetapi mungkin tingkat resiko yang mereka hadapi sebenarnya jauh lebih tinggi dari yang kita banyangkan karena tekanan-tekanan yang diciptakan oleh situasi gawat darurat. berbagai situasi yang memungkinkan membuat anak menjadi sangat terabaikan atau kurang mendapat perhatian dari orang tua atau pengasuhnya dikarenakan oleh keberadaan pengasuh mereka yang mengalami trauma serius. Ada juga karena kondidi pengasuh yang harus bekerja jauh sehingga anak kurang mendapat perhatian dari pengasuhnya. Hal serupa ini membuat kebutuhan anak menjadi terabaikan dalam waktu yang relatif lama. Hal lain yang menjadi factor penyebabnya yakni tekanan sosialekonomi keluarga yang terus meningkat, kadang-kadang diperburuk dengan meningkatnya konflik keluarga dan masyarakat, dapat menciptakan alasanalasan meningkatnya tingkatkekerasan secara umum. Oleh karena itu setiap anak-anak yang berada dalam sebuah situasi darurat bencana membutuhkan dukungan dan strategi-strategi yang berbeda untuk menjamin perlindungan terhadap mereka.

Yang menjadi dasar hukum Perlindungan hak-hak anak adalah Konvensi PBB tentang Hak-Hak Anak Tahun 1989 (KHA). Konvensi ini merupakan pembahasan tentang pelacuran anak, pornografi anak, dan perdagangan anak dengan tujuan seksual. Selain itu dibahas pula hal-hal yang menjadi hak anak, termasuk perlindungan yang harus diberikan 
secara universal kepada semua anak maupun remaja di bawah usia 18 tahun.

Walaupun ada sejumlah hukum, traktat dan konvensi yang memberikan perlindungan bagi hak-hak anak, tetapi harus diingat bahwa dalam kekacauan dan gangguan yang biasanya terjadi dalam situasi bencana maupun konflik, maka tatanan hukum yang akan memungkinkan untuk menjalankan instrumen-instrumen perlindungan hakhak anak akan sulit untuk diakses atau bahkan tidak tersedia. Dalam sebuah bencana alam seperti bencana gempa bumi dan tsunami yang melanda Asia pada tahun 2004, sistem hukum di negara-negara yang diterjang bencana tsunami tersebut pada umumnya dapat berfungsi atau berjalan walaupun dalam keadaan yang kurang optimal (Delaney, 2006). Kondisi tersebut akan lebih lemah apabila terjadi situasi bencana seriusdalam waktu yang lama dan berkepanjangan seperti misalnya pandemi Covid-19 pada saat sekarang ini. Adapun hak-hak dasar anak yang diatur dalam Konvensi Hak Anak yang disetujui oleh majelis umum Perserikatan Bangsa-Bangsa (PBB) pada tanggal 20 November 1989 antara lain sebagai berikut:
1. Hak untuk mendapatkan perlindungan dari tindakan diskriminasi (Pasal 2);

2. Hak untuk mendapatkan perlindungan hukum (Pasal 3 ayat (1));

3. Hak untuk mendapatkan kesejahteraan (Pasal 3 ayat (2));

4. Hak untuk mendapatkan perlindungan atas keselamatan dan layanan kesehatan (Pasal 3 ayat (3));

5. Hak untuk hidup (Pasal 6 ayat (1));

6. Hak untuk tumbuh dan berkembang (Pasal 6 ayat (2));

7. Hak untuk mendapatkan identitas dan kewarganegaraan (Pasal 7 ayat (1) dan Pasal 8) ;

8. Hak untuk tidak dipisahkan dengan orangtuanya (Pasal 9 dan Pasal 10);

9. Hak untuk mendapat perlindungan dari kejahatan perdagangan anak (Pasal 11 ayat (1));

10. Hak untuk menyampaikan pendapat (Pasal 12 dan Pasal 13);

11. Hak kebebasan berpikir dan beragama (Pasal 14 ayat (1));

12. Hak kebebasan berserikat dan berkumpul (Pasal 15 ayat (1));

13. Hak untuk mendapatkan perlindungan dari upaya eksploitasi dan kejahatan seksual (Pasal 19);

14. Hak untuk dapat diadopsi secara layak (Pasal 21); 
15. Hak untuk mendapatkan pendidikan (Pasal 28 dan Pasal 29);

16. Hak untuk beristirahat dan bersenang-senang (Pasal 31).

Dengan diratifikasnya Konvensi Hak Anak menjadi undang-undang, maka seluruh elemen negara berkewajiban untuk melindungi dan menjaga hak dasar anak. Oleh sebab itu pemerintah khususnya pemerintah daerah harus lebih serius dalam melindungi hak anak dan lebih peka dalam mendengarkan keluh kesah maupun aspirasi yang disampaikan oleh anak. Apabila pemerintah khususnya pemerintah daerah lalai dalam melindungi dan memenuhi hak-hak anak, maka pemerintah secara tak langsung telah mememulai kehancuran negara dimasa depan.

Agar pemerintah dapat bekerja dengan optimal dalam melindungi dan memenuhi hak dasar anak, masyarakat haruslah mengambil andil dengan aktif mengedukasi anak dan mengawasi perkembangan anak serta memberi masukan kepada pemerintah tentang kebijakan-kebijakan pemerintah yang merugikan hak-hak anak, ataupun memberikan masukan kepada pemerintah untuk membuat suatu regulasi yang dapat membantu upaya pemenuhan hak dasar anak dan melindungi masa tumbuh dan berkembang anak.

\section{Perlindungan Hak Dasar Anak di Kota Medan}

Kota Medan sebagai kota pelabuhan dan pusat perdagangan di Pulau Sumatera telah sejak dahulu menjadi pintu masuk berbagai komoditi perdagangan yang diimpor dari luar negeri. Dengan padatnya aktifitas perdagangan di Kota Medan tentunya menarik perhatian orang-orang baik dari dalam maupun luar negeri untuk datang ke Kota Medan dengan tujuan berdagang, bekerja, berwisata, dan lain sebagainya. Hal ini tentunya memberikan efek yang positif bagi pertumbuhan ekonomi Kota Medan dan kesejahteraan masyarakat Kota Medan.

Namun tingginya aktifitas perdagangan dan lalu lintas orang yang keluar dan masuk di Kota Medan juga memberikan dampak yang tidak baik seperti misalnya produk atau orang yang berasal dari luar Kota Medan memiliki potensi untuk membawa atau menyebarkan suatu wabah penyakit ataupun hama. Hal ini terbukti di saat pandemi Covid-19 mewabah, Kota Medan menjadi wilayah dengan jumlah pasien 
positif dan penyebaran pandemi tertinggi di Provinsi Sumatera Utara.

Walaupun pemerintah Kota Medan telah berupaya dengan maksimal untuk memutus penyebaran pandemi Covid-19 akan tetapi diakibatkan aktifitas perdagangan dan lalu lintas orang yang keluar dan masuk ke Kota Medan sangat tinggi, pandemi Covid-19 menjadi sulit untuk di akhiri.

Pandemi Covid-19 memberikan dampak yang sangat buruk terhadap kesehatan dan bahkan dapat menyebabkan kematian. Ketakutan akan bahaya pandemi Covid-19 telah menimbulkan kepanikan di masyarakat. Untuk mengatasi pandemi Covid-19, pemerintah Kota Medan telah mengambil langkah-langkah pencegahan dan penanganan seperti menerapkan protokol kesehatan (mewajibkan penggunaan masker, mewajibkan cek suhu tubuh sebelum memasuki fasilitas publik, penyemprotan disinfektan, menjaga jarak saat berinteraksi, meliburkan sekolah, menutup sementara beberapa jenis usaha seperti hotel-hotel dan pusat-pusat perbelanjaan) sesuai dengan instruksi dari pemerintah pusat.

Dari aktifitas pencegahan dan penanganan Covid-19 yang dilaksanakan oleh pemerintah Kota Medan melalui Gugus Tus Percepatan Penanganan
Covid-19 Kota Medan, beberapa aktifitas seperti penutupan sementara usaha yang dapat menimbulkan orang berkerumun dalam jumlah besar seperti Warung Internet, Mall, Hotel, dan beberapa pabrik yang karyawannya terindikasi positif Covid-19, telah menimbulkan kesulitan ekonomi dan berkurangnya pendapatan masyarakat.

Untuk itu pemerintah Kota Medan menerbitkan produk hukum daerah berupa Peraturan Walikota Medan Nomor 11 Tahun 2020 tentang Karantina Kesehatan Dalam Rangka Percepatan Penanganan Corona Virus Disease 2019 (Covid-19) Di Kota Medan, sebagai payung hukum lokal penanganan Covid19 beserta dampak-dampak yang dihasilkannya.

Produk hukum daerah yang efektif dan berkualitas adalah produk hukum yang dalam hal konten dan persiapan teknisnya sesuai dengan hukum dan peraturan yang lebih tinggi serta dapat memecahkan masalah dan menjawab kebutuhan masyarakat. Produk hukum daerah yang dibuat juga harus sesuai dengan kebutuhan, berlaku secara efektif atau tepat sasaran atau mencapai tujuan dan pada tingkat implementasi dapat bermanfaat bagi seluruh lapisan masyarakat di daerah tersebut (MYA Syaputra dan Dani Sintara, 2019). 
Dari pengertian produk hukum yang baik dan efisien tersebut di atas, Peraturan Walikota Medan Nomor 11 Tahun 2020 tentang Karantina Kesehatan Dalam Rangka Percepatan Penanganan Corona Virus Disease 2019 (Covid-19) Di Kota Medan tidaklah memberikan manfaat kepada seluruh lapisan masyarakat di Kota Medan khususnya anak dikarenakan Peraturan Walikota Medan Nomor 11 Tahun 2020 tentang Karantina Kesehatan Dalam Rangka Percepatan Penanganan Corona Virus Disease 2019 (Covid-19) Di Kota Medan tidaklah mengakomodir kepentingan perlindungan anak dan juga pemenuhan hak-hak dasar anak.

Seperti yang telah dibahas di pembahasan sebelumnya, di masa bencana yang berkepanjangan seperti pandemi Covid-19 sekarang ini, anak dan hak-hak anak beserta kebutuhan anak lainnya cenderung diabaikan dan diterlantarkan. Bahkan pada saat kesulitan ekonomi terjadi, anak cenderung menjadi bahan pelampiasan kekesalan yang mengakibatkan terjadinya Bullying dan kekerasan kepada anak, ekploitasi untuk mendapatkan uang, bahkan penelantaran.

Terkait dengan ekploitasi anak, dimasa pandemi seperti sekarang ini tidak jarang orang tua memanfaatkan anak nya yang sedang tidak bersekolah karena sekolahnya sedang diliburkan. Bahkan ada orang tua yang memanfaatkan anaknya untuk mengemis. Hal ini dibuktikan melalui peninjauan di lapangan bahwa semakin banyak anak yang menjadi pengemis di Kota medan saat pandemi Covid-19. Sebagai contoh, di beberapa Mini Market di jalan Halat Medan, banyak anak-anak usia sekolah yang duduk diemperan mini market dengan membawa wadah plastik untuk mengemis meminta sedekah dari orang yang berbelanja. Bahkan anak-anak tersebut mengemis sampai dini hari dan sebahagian ada yang tidur di emperan mini market. Selain itu terkadang anakanak tersebut ditemani orang beberapa orang wanita berusia 30 sampai 50 tahun yang tidak diketahui apakah wanita tersebut merupakan kerabat dari anak yang mengemis. Selain anak usia sekolah, ada juga anak usia balita yang dibawa oleh ibunya untuk mengemis di mini market.

Terkait dengan hak pendidikan, dikarenakan status zona merah yang dimiliki Kota Medan, anak-anak masih tidak dapat bersekolah dengan cara bertatap muka pada saat new normal dimulai. Oleh karena itu alternatif yang 
dapat dijalankan untuk memenuhi hak pendidikan anak adalah sekolah dengan cara online. Akan tetapi kendalanya adalah tidak semua sekolah ataupun siswa dapat melaksanakan sekolah online. Hal ini dikarenakan faktor-faktor seperti, sulitnya jaringan internet di daerah miskin, keterbatasan pihak sekolah untuk menyelenggarakan pendidikan berbasis online dan ketidakmampuan orang tua siswa untuk membelikan gadget seperti smartphone ataupun paket data yang memiliki kecepatan internet yang tinggi.

Pemerintah Kota Medan Beserta Dewan Perwakilan Rakyat Daerah Kota Medan harulah segera menerbitkan produk hukum daerah setingkat Peraturan Daerah (Perda) untuk menjamin perlindungan dan pemenuhan hak-hak dasar anak di masa pandemi Covid-19. Produk hukum yang akan menjadi payung hukum perlindungan dan pemenuhan hak-hak dasar anak tersebut haruslah setingkat Perda dikarenakan Perda dapat memuat sanksi pidana di dalamnya sehingga dapat memaksimalkan efek perlindungan terhadap anak. Perda tersebut juga harus mengatur mengenai kewajiban pemerintah Kota Medan untuk menyediakan fasilitas mau pun sarana dalam pelaksanaan sekolah online, bahkan kalau diperlukan, pemerintah Kota Medan harus dapat memberi pinjaman smartphone kepada siswa yang tidak mampu agar siswa tersebut tetap dapat bersekolah secara online.

Dalam perlindungan anak terhadap tindakan kekerasan dan ekploitasi, pemerintah harus menguatkan Dinas Perlindungan Perempuan Dan Anak Kota Medan, dan juga bekerjasama Komisi Perlindungan Anak Kota Medan untuk melaksanakan pengawasan ekstra agar walaupun sedang dalam masa pandemi Covid-19, anak-anak di Kota Medan tetap dapat tumbuh dan berkembang secara normal dan optimal.

\section{SIMPULAN}

Anak sebagai generasi penerus merupakan tumpuan masa depan bangsa. Oleh karena itu pemenuhan hak dasar anak merupakan kewajiban yang harus diwujudkan oleh setiap elemen bangsa. Akan tetapi di masa pandemi sekarang ini, Peraturan Walikota Medan Nomor 11 Tahun 2020 tentang Karantina Kesehatan Dalam Rangka Percepatan Penanganan Corona Virus Disease 2019 (Covid-19) Di Kota Medan, masihlah belum mengakomodir pemenuhan hak dasar anak. Pemerintah Kota Medan Beserta Dewan Perwakilan Rakyat Daerah Kota Medan harulah segera menerbitkan 
produk hukum daerah setingkat Peraturan Daerah (Perda) untuk menjamin perlindungan dan pemenuhan hak-hak dasar anak di masa pandemi Covid-19. Produk hukum yang akan menjadi payung hukum perlindungan dan pemenuhan hak-hak dasar anak tersebut haruslah setingkat Perda dikarenakan Perda dapat memuat sanksi pidana di dalamnya sehingga dapat memaksimalkan efek perlindungan terhadap anak. Perda tersebut juga harus mengatur mengenai kewajiban pemerintah Kota Medan untuk menyediakan fasilitas mau pun sarana dalam pelaksanaan sekolah online; perlindungan dan pengawasan anak dari tindak kekerasan, serta perlindungan dan pengawasan anak dari tindakan eksploitasi.

\section{DAFTAR PUSTAKA}

Arief, B. N. (2005). Beberapa Aspek Kebijakan Penegakan dan Pengembangan Hukum Pidana. Bandung: Citra Aditya Bakti.

Delaney, S. (2006). Melindungi Anak-Anak Dari Eksploitasi Seksual \& Kekerasan Seksual Dalam Situasi Bencana \& Gawat Darurat. Medan: ECPAT Internasional.

Fahlevi, R. (2015). Aspek Hukum Perlindungan Anak dalam Prespektif Hukum Nasional. Lex Jurnalica (Journal of Law), 178.

Firdaus, I. (2015, Juli 30). Pemenuhan Hak Partisipasi Anak Dalam Pembangunan. Majalah Humanis (Warta Hak Asasi Manusia), p. Volume XI.

Gosita, A. (2004). Masalah Korban Kejahatan. Jakarta: PT. Bhuana Ilmu Populer.

MYA Saputra \& Mirza Nasution. (2018). Settlement of Indonesian Disorientation Democracy:
Perspective of Legal Culture. E3S Web of Conferences, 3.

MYA Syaputra dan Dani Sintara. (2019, Agustus). Revitalization of Malay Cultural Values in Regional Regulation of Spatial and Region in Medan City. Budapest International Research and Critics Institute-Journal (BIRCI-Journal), 2(3), 358.

Pasys, R. (2020, Juni 04). Apa Itu Zona Hijau, Zona Merah Hingga Zona Hitam Terkait Virus Corona? Retrieved from kids.grid.id: https://kids.grid.id/read/472179856/ap a-itu-zona-hijau-zona-merah-hinggazona-hitam-terkait-virus-corona?page=all

Said, M. F. (2018). Perlindungan Hukum terhadap Anak dalam Perspektif Hak Asasi Manusia. Jurnal Cendekia Hukum, 145-146.

Soerjono Soekanto dan Sri Mamudji. (2003). Penelitian Hukum Normatif Suatu Tinjauan Singkat. Jakarta: PT. Rajagrafindo Persada.

Sunggono, B. (2003). Metodologi Penelitian Hukum. Jakarta: PT. Rajagrafindo Persada.

Syamsuddin, A. (2014). Tindak Pidana Khusus. Jakarta: Anak Negeri Publisindo.

Syaputra, M. Y. (2017). Kajian Hukum Pemberlakuan Perda Kota Medan Nomor 6 Tahun 2003 Perspektif Utilities Theory. Jurnal Mercatoria, 208.

Tarigan, G. N. (2020, Juni 03). Terungkap 75 Persen Uang Sekolah Swasta di Medan Menunggak, Pemko Tegaskan Agar Patuhi Surat Edaran. Retrieved from medan.tribunnews.com:

https://medan.tribunnews.com/2020/06 /03/terungkap-75-persen-uang-sekolahswasta-di-medan-menunggak-pemkotegaskan-agar-patuhi-surat-edaran

Wismabrata, M. H. (2020, Juni 23). Kisah Pilu 2 Anak Tiri Dibunuh Ayah di Medan, Berawal Minta Dibelikan Es. Retrieved from kompas.com: https://medan.kompas.com/read/2020/0 6/23/06190091/kisah-pilu-2-anak-tiridibunuh-ayah-di-medan-berawal-mintadibelikan-es?page=all 